\title{
Nature-based solutions to climate change mitigation and adaptation in urban areas: perspectives on indicators, knowledge gaps, barriers, and opportunities for action
}

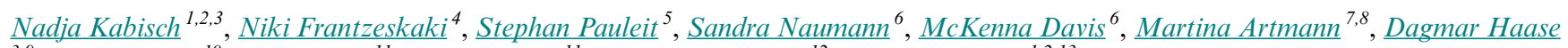 \\ ${ }^{3,9}$, Sonja Knapp $^{10}$, Horst Korn $^{11}$, Jutta Stadler $^{11}$, Karin Zaunberger $^{12}$ and Aletta Bonn $^{1,2,13}$
}

\begin{abstract}
Nature-based solutions promoting green and blue urban areas have significant potential to decrease the vulnerability and enhance the resilience of cities in light of climatic change. They can thereby help to mitigate climate change-induced impacts and serve as proactive adaptation options for municipalities. We explore the various contexts in which nature-based solutions are relevant for climate mitigation and adaptation in urban areas, identify indicators for assessing the effectiveness of nature-based solutions and related knowledge gaps. In addition, we explore existing barriers and potential opportunities for increasing the scale and effectiveness of nature-based solution implementation. The results were derived from an inter- and transdisciplinary workshop with experts from research, municipalities, policy, and society. As an outcome of the workshop discussions and building on existing evidence, we highlight three main needs for future science and policy agendas when dealing with nature-based solutions: (i) produce stronger evidence on nature-based solutions for climate change adaptation and mitigation and raise awareness by increasing implementation; (ii) adapt for governance challenges in implementing nature-based solutions by using reflexive approaches, which implies bringing together new networks of society, nature-based solution ambassadors, and practitioners; (iii) consider socio-environmental justice and social cohesion when implementing nature-based solutions by using integrated governance approaches that take into account an integrative and transdisciplinary participation of diverse actors. Taking these needs into account, nature-based solutions can serve as climate mitigation and adaptation tools that produce additional cobenefits for societal well-being, thereby serving as strong investment options for sustainable urban planning.
\end{abstract}

Key Words: climate change; cobenefits; governance; nature-based solutions; urban areas

\section{INTRODUCTION}

Climate change is already affecting Europe's ecosystems and is expected to pose further threats to biodiversity and ecosystem functioning in the future (Schröter et al. 2005, Grimm et al. 2008, Science for Environment Policy 2015). Foreseen effects relate to the establishment of alien plant species, degradation of habitats, decreases in the distribution of native species that are mal-adapted to heat and drought, and water scarcity (Schröter et al. 2005, Knapp et al. 2010, European Environmental Agency 2012). Climate change also significantly impacts society, with the most considerable effects likely to be experienced in urban areas (White et al. 2005). The main risks include, for example, the effects of heat waves and other extreme events (e.g., flooding, droughts, etc.), changes in patterns of infectious diseases, and the impacts on food yields and freshwater supplies (McMichael et al. 2008). Declining water availability in cities and an increasing risk of forest fires in peri-urban areas are additional threats faced by urban populations (Schröter et al. 2005, European Environmental Agency 2012).

In addition to climate change, ongoing urbanization and the accompanying increases in the number and size of cities threaten ecosystems as these processes drive a large-scale conversion of rural to urban landscapes (Seto et al. 2011). It is estimated that only $40 \%$ of the urban areas that are foreseen to exist by 2030 have already been built, implying that significant additional urban development will take place in the next 15 years (Secretariat of the Convention on Biological Diversity 2012). A range of interlinked pressures, such as the loss or degradation of natural areas, soil sealing, and the densification of built-up areas pose further challenges to ecosystem functionality and therewith human well-being in cities around the world. These processes may lead to biodiversity loss or a reduction in the general functioning of ecosystems, and therewith in the provisioning of services they provide (Artmann and Breuste 2015, Haase et al. 2014).

Given these growing threats to biodiversity and society, green and blue spaces within urban areas are being increasingly recognized for their capacity to not only support biodiversity conservation (Niemela 1999, Goddard et al. 2010), but also to generate additional environmental, economic, and social benefits (Haase et al. 2014, Kabisch et al. 2015a) and to foster the functioning of ecosystems as essential backbones to climate change mitigation and adaptation (European Commission 2015). The concept of nature-based solutions $(\mathrm{NbS})$ is one of several concepts that promote the maintenance, enhancement, and restoration of biodiversity and ecosystems as a means to address multiple concerns simultaneously. Other related concepts include

${ }^{1}$ Department Ecosystem Services, Helmholtz Centre for Environmental Research - UFZ, ${ }^{2}$ German Centre for Integrative Biodiversity Research (iDiv) Halle-Jena-Leipzig, ${ }^{3}$ Department of Geography, Humboldt-Universität zu Berlin, ${ }^{4}$ DRIFT - Dutch Research Institute For Transitions, Erasmus University Rotterdam, ${ }^{5}$ Strategic Landscape Planning and Management, Technical University of Munich, ${ }^{6}$ Ecologic Institute, Berlin, ${ }^{7}$ Leibniz Institute of Ecological Urban and Regional Development (IOER), Dresden, ${ }^{8}$ Research Group Urban and Landscape Ecology, University of Salzburg, ${ }^{9}$ Department Computational Landscape Ecology, Helmholtz Centre for Environmental Research-UFZ, ${ }^{10}$ Department Community Ecology, Helmholtz Centre for Environmental Research-UFZ, ${ }^{11}$ German Federal Agency for Nature Conservation, ${ }^{12}$ European Commission, Environment Directorate General, Brussels, ${ }^{13}$ Friedrich Schiller University Jena 
"ecosystem-based adaptation," "green infrastructure," "ecosystembased disaster risk reduction," and "natural water retention measures." In most cases, these approaches are complementary, have considerable overlap, and are also used in the nonurban context. All of these terms focus on developing systemic approaches utilizing concrete implementation actions as solutions to address the outlined impending pressures and risks. The development of systemic solutions suggests the optimized generation of multiple ecosystem services with low required physical resources (Everard and McInnes 2013). In this paper we focus on $\mathrm{NbS}$ as an innovative approach, which builds on these concepts and further addresses societal challenges in cities, developing pathways toward sustainable urbanization.

Nature-based solutions can be characterized as "[...] the use of nature in tackling challenges such as climate change, food security, water resources, or disaster risk management, encompassing a wider definition of how to conserve and use biodiversity in a sustainable manner" (Balian et al. 2014:5). Relevant actions falling into this category include those "[...] which are inspired by, supported by or copied from nature [...]" (European Commission 2015:4). They include green roofs and walls that serve to reduce temperatures and to increase related energy savings through reduced cooling loads (Alexandri and Jones 2008) as well as improve air quality. Another $\mathrm{NbS}$ is the increased provision of urban green spaces such as parks and street trees to ameliorate high temperature in cities (Gill et al. 2007, Bowler et al. 2010).

In urban landscapes, the cobenefits of $\mathrm{NbS}$ are being increasingly recognized as a result of increased provisioning and improved availability of urban green spaces. Such benefits include, for example, improved quality of life, mental and physical health, and reinforced cultural identities, supporting a sense of belonging and place (Keniger et al. 2013, Hartig et al. 2014). Taking this aspect of multifunctionality into account and considering the plethora of cobenefits produced, $\mathrm{NbS}$ are seen to often represent more efficient and cost-effective solutions to climate change threats than more traditional approaches, such as conventional sewage or air conditioning systems (European Commission 2015).

The positive effects of green and blue spaces as $\mathrm{NbS}$ to climate change mitigation and adaptation are highlighted in several reports, scientific papers, and information platforms (such as Climate-ADAPT by the European Environmental Agency, http:// climate-adapt.eea.europa.eu/). In an urban context, there is a clear need to promote swift implementation using current knowledge and experience while continuing to further explore what specific actions may be required, and what the challenges and issues might be in different places and for different ecosystems and species. An important aspect of this is to learn from action that is already taking place. Here, there is great potential to share information among different countries and to learn from existing approaches and experiences. Improving knowledge on (i) the feasibility and opportunities of specific actions for enhancing and implementing $\mathrm{NbS}$ in urban areas, (ii) their associated effectiveness, and (iii) the potential barriers and opportunities to action at the city level will help to build momentum. However, knowledge gaps exist with regard to long-term benefits as well as the contribution of $\mathrm{NbS}$ to increasing the resilience of urban areas against foreseen environmental changes (Naumann et al. 2015). The development of indicators can help to assess and demonstrate the usefulness and effectiveness of $\mathrm{NbS}$ and increase the measurability of their effects. Moreover, indicators can help to systematically evaluate $\mathrm{NbS}$ implementation projects and increase comparability and measurability, thereby adding to the evidence base for $\mathrm{NbS}$.

Against this backdrop, we present insights from an inter- and transdisciplinary expert workshop on "Nature-based solutions to climate change mitigation and adaptation in urban areas," which took place at the International Academy for Nature Conservation, Island of Vilm, Germany in March 2015. Participants discussed the following interlinked issues:

- Indicators for measuring the effectiveness of $\mathrm{NbS}$ for climate change mitigation and adaptation and associated cobenefits;

- Knowledge gaps relating to the effectiveness of NbS in cities;

- Potential barriers for bringing NbS into action; and

- Opportunities facilitating action for $\mathrm{NbS}$.

\section{METHODOLOGY}

The workshop aimed to showcase and explore examples of good practices of $\mathrm{NbS}$ to climate change mitigation and adaptation in Europe's urban areas and their surrounding landscapes, and to identify indicators of success for $\mathrm{NbS}$, challenges of implementation, and other knowledge gaps. An explicit goal was to assess how the concept of $\mathrm{NbS}$ can help conservation to work across sectors in collaboration with different disciplines such as urban planning, architecture, ecology, and public health. Therefore, the participating 34 experts from seven European countries represented research, policy and society in the fields of urban planning, geography, ecology, biology, and urban sociology. Participants from policy came from national and city administrations, as well as the European Commission. Participants from society represented local NGOs and community groups (for detailed information on the workshop program, see Kabisch et al. 2015b).

All participants convened and participated in a facilitated discussion and dialogue about $\mathrm{NbS}$. The workshop was organized into two full days with different sessions, including keynote presentations, panel discussions, and group activities and discussions. The panel discussions and small-group discussions were structured and lead by specific questions addressing the four thematic areas of this paper: indicators, knowledge gaps, opportunities, and barriers of $\mathrm{NbS}$. All of the information and knowledge gained from the workshop discussions was collected using pin boards, minutes, several note takers, and photos. Keynote presentations introduced theoretical considerations, existing evidence from research, case studies, and highlighted knowledge gaps and potential challenges for $\mathrm{NbS}$ implementation. Subsequent group exercises explored these issues in more depth in a world café format. Participants were asked to discuss and brainstorm different issues for a certain period on each topic; pin boards were prepared accordingly for collecting information and facilitating discussions. Four of the participants facilitated this session, took notes, and structured the discussion. Results of the group work were presented in a plenary session for further discussion to deepen the level of understanding across the groups. 
Fig. 1. Potential indicators concerning the effectiveness of nature-based solutions ( $\mathrm{NbS})$ for climate change adaptation and mitigation and associated cobenefits.

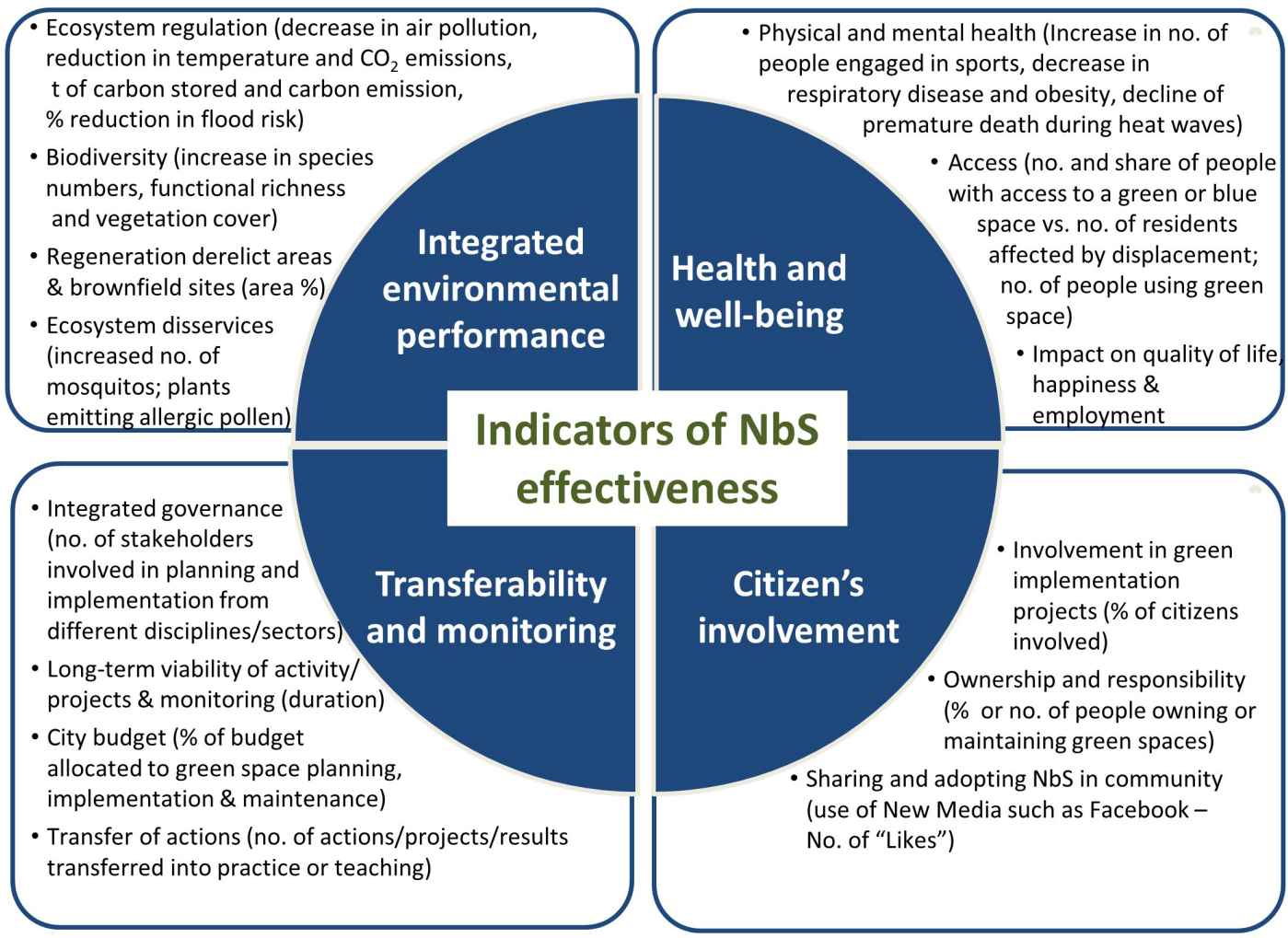

\section{RESULTS AND DISCUSSION}

Indicators for measuring the effectiveness of $\mathrm{NbS}$ for climate change mitigation and adaptation and associated cobenefits

Establishing a sound evidence base for $\mathrm{NbS}$ requires several preconditions, such as streamlining assessment approaches and including indicators focusing on measuring the effectiveness of $\mathrm{NbS}$ for climate change adaptation and mitigation. An evidence base can in turn be used to share information among different countries and disciplines and to facilitate mutual learning from NbS-related experiences, the challenges cities may face, or the opportunities that could foster action for $\mathrm{NbS}$. Case studies can serve to illustrate the added value of $\mathrm{NbS}$ for, e.g., climate change resilience (especially in combating the urban heat island effect), reducing noise, improving air quality, and creating recreational areas (European Commission 2015).

One of the fundamental needs identified in the field of $\mathrm{NbS}$ is to establish targeted indicators. An indicator is defined here as a measure or metric based on verifiable data that condenses complexity and conveys information (Haase et al. 2014). Indicators could be used for efficiently measuring, analyzing, monitoring, and communicating not only the effectiveness of NbS, but also their characteristics (see also Sparks et al. 2011). In terms of communication, indicators could help to track and impart how green and blue spaces in cities provide benefits in terms of adapting to climate change, and therewith to support human well-being. Indicator values may also inform decisions and actions by providing convincing arguments for decision makers in urban administrations to, for example, consider $\mathrm{NbS}$ in budget allocations.

A wide range of potential indicators were identified over the course of the expert workshop. The identified indicators had a specific focus on comparative assessments of $\mathrm{NbS}$ both at city level and between cities (Fig. 1). Numerous further indicators are referred to in the literature (Colls et al. 2009, Cowan et al. 2010, Doswald and Osti 2011, Naumann et al. 2014), but the indicators identified in the workshop are suggested to cover four important aspects that should be considered in the assessment of NbS: (1) indicators for integrated environmental performance, (2) indicators of human health and well-being, (3) indicators for citizen involvement, and (4) indicators of transferability. A unique aspect of the developed indicator sets is that they point to an assessment of the supply-side (environmental performance) related to urban ecosystem services and $\mathrm{NbS}$ as well as to the demand-side (health and well-being, citizen's involvement, as well as transferability and monitoring), where socio-demographic and socioeconomic data need to be included in an assessment.

Integrated environmental performance indicators predominantly relate to regulating ecosystem services, such as climate regulation measured by temperature reduction, air quality regulation through a decrease of air pollutants, and flood control by mitigating extreme events and increasing local water retention. Some indicators refer to biodiversity, such as the share of vegetation cover (with vegetation cover per se not being 
necessarily diverse but large vegetated areas providing room for biodiversity; Beninde et al. 2015). This points to a general increase in urban green spaces, which also includes the share of brownfield sites in a given area that have been developed into near natural green spaces. In a comprehensive review that focuses on studies assessing urban ecosystem services, Haase et al. (2014) showed that indicators for local climate and air quality regulation and carbon sequestration and storage were predominantly applied in a number of studies, while fewer studies used indicators for cultural or provisioning services. The lack of data availability was discussed as one reason for this. Furthermore, indicators related to ecosystem disservices of green and blue infrastructure were discussed in the workshop. Ecosystem disservices can be defined as ecosystem functions that are rather negatively perceived for human well-being (Lyytimäki and Sipilä 2009). Related indicators are increasing numbers of mosquitoes or increasing number of plants emitting allergic pollen. Disservices only started to be recognized in ecosystem services research (Lyytimäki and Sipilä 2009, von Döhren and Haase 2015) and were not mentioned in the prominent basic ecosystem services publications (de Groot et al. 2002, Millennium Ecosystem Assessment 2005, TEEB 2011).

Indicators related to health and well-being concern the cobenefits of $\mathrm{NbS}$ and include physical and mental health indicators, as well as the spatial availability of green and blue spaces. Physical and mental health indicators were suggested by workshop participants to measure the number of people participating in outdoor sports activities and specific health benefits, such as reduced rates of respiratory diseases or obesity. A number of studies have illustrated the positive health effects from living in close proximity to green spaces (for an overview, see Hartig et al. 2014). Mental health has also been suggested to be measured through happiness indicators for life satisfaction ratings (White et al. 2013, Carrus et al. 2015). In addition, indicators addressing social and environmental justice issues were proposed at the workshop, such as measurements of green space availability through the number or share of residents affected by displacement or increasing segregation. The installation of new or restoration of existing green spaces might be beneficiary as an $\mathrm{NbS}$ for climate change adaptation or mitigation, but may simultaneously lead to increases in land prices and rent because of increased attractiveness of the area. In turn, those residents for which the green spaces would be most beneficial sometimes cannot profit from the natural area because of displacement processes. Such effects are called the "green paradox" (Wolch et al. 2014), ecogentrification (Irvine et al. 2013, Haffner 2015), ecological gentrification (Dooling 2009), or environmental gentrification (Checker 2011).

The remaining two sets of identified indicators relate to the processes of developing and managing $\mathrm{NbS}$. Experts in the workshop suggested that one set of indicators relate to (the number or percentage of) citizens' involvement in green implementation projects and citizens owning or maintaining a green space (see also Shandas and Messer 2008). Indicators related to citizens' involvement may also include measurements on how information on $\mathrm{NbS}$ is shared and adopted in the community. This could be measured by the information gained through new media, such as Facebook and the number of "likes" for a certain topic or post.
Finally, the fourth set of proposed indicators relates to the transfer of model projects into general practice and monitoring of projects. This set may include implementation measures and integrated governance approaches, measured by the number of stakeholders coming from different sectors involved in planning and implementation as well as the number of policy officers and planners that employ the concept of $\mathrm{NbS}$ for policy practice in terms of forming planning agendas, plans, and integrating it in the planning discourse. Some aspects were intensively discussed in the workshop, including timing, financial aspects, and monitoring. Monitoring relates to concerns of whether or not monitoring is encouraged (e.g., monitoring of a strategy's implementation) and, if indeed included, the duration for which these monitoring activities are foreseen. Indicators relating to a city's administrative budget include the percentage of budget allocated to green space planning, implementation, maintenance, and monitoring of implementation projects and strategies.

\section{Knowledge gaps relating to the effectiveness of $\mathrm{NbS}$ in cities}

Knowledge gaps remain with regard to a number of issues surrounding the effectiveness of $\mathrm{NbS}$ for climate change adaptation and mitigation and their impacts on the natural and social environment. More specifically, four main knowledge gaps were identified by the workshop participants (Fig. 2) relating to: (1) the effectiveness of $\mathrm{NbS}$; (2) relationship between $\mathrm{NbS}$ and society; (3) design of $\mathrm{NbS}$; and (4) implementation aspects.

The first group of knowledge gaps focuses on the effectiveness of $\mathrm{NbS}$ related to an incomplete evidence base concerning trade-offs and synergies between $\mathrm{NbS}$ for climate change mitigation/ adaptation and biodiversity, human health, or social and economic aspects (Hartig et al. 2014, World Health Organization and Secretariat of the Convention on Biological Diversity 2015). Substantial scientific evidence outlines the linkages and causal effects between urban green spaces and positive effects on human health and well-being; however, these relationships remain contested regarding the degree of causality and effectiveness. Although a number of studies found beneficial health effects (for a current comprehensive overview, see World Health Organization and Secretariat of the Convention on Biological Diversity 2015), others could not identify any association between green space availability and general health improvements (Richardson et al. 2013). Furthermore, knowledge on the impacts of climate change on biodiversity and its linkages to ecosystem services and the effectiveness of $\mathrm{NbS}$ in cities is limited because biodiversity in cities is exposed to multiple stressors simultaneously, such as high levels of pollution, fragmentation, and disturbance (Niemela 1999). Further, biodiversity and ecosystem services do not necessarily enhance each other (Ziter 2015).

The appropriate time scale of $\mathrm{NbS}$ implementation is another aspect that is unclear within this gap category. It remains unclear which approaches would be more effective in the long term and which would be more effective immediately after implementation. These questions are relevant when it comes to, for instance, different approaches to stormwater management such as bioswales, rain gardens, and roof-greening. Generating this type of information will require longer term research, data collection, and observations. Sharing information and applying comparative approaches can be used not only to map and identify similarities 
Fig. 2. Knowledge gaps for the various dimensions nature-based solutions (NbS) can affect.

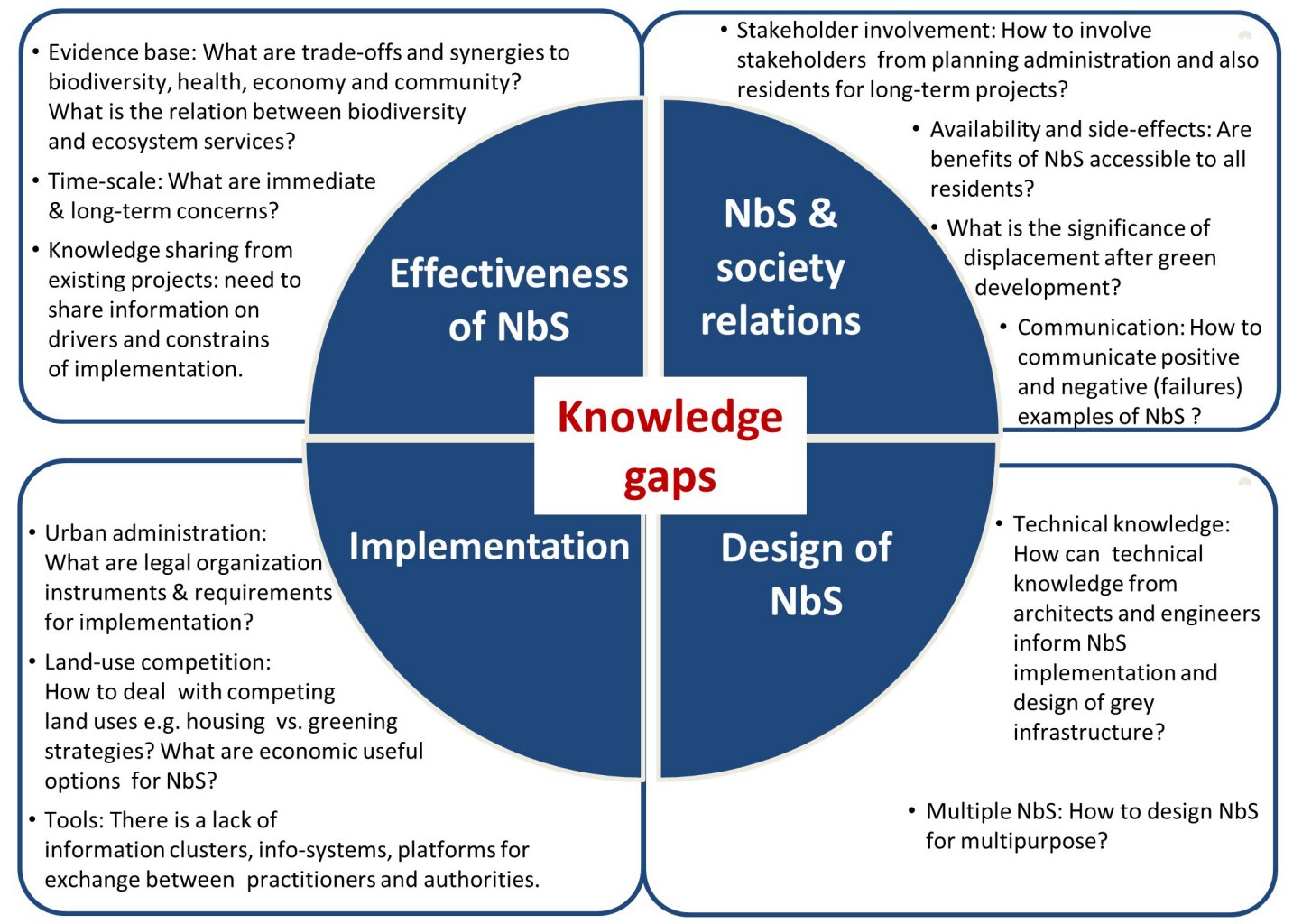

and differences in the form of patterns or meta-level strategies, but also to examine by comparison the enabling or inhibiting context conditions (governance and socioeconomic) that affect the establishment and scaling of $\mathrm{NbS}$ across cities. Certainly, a number of city projects concerning climate change through urban green areas exist and have been implemented; however, a shared knowledge base in general and particularly for urban areas continues to be lacking because of uncertainties on how to best share information and regarding the drivers and constraints of implementation.

The second knowledge gap concerns the relationship between $\mathrm{NbS}$ and society and, more specifically, the stakeholder involvement and impact of human-nature interactions in forming or altering lifestyles, beliefs, and preferences while also considering place-impacts such as displacement and gentrification. Questions were raised during the workshop regarding approaches on how to involve stakeholders from planning administrations and residents in long-term projects, as well as if all residents can benefit from implemented $\mathrm{NbS}$ or if benefits are only accessible to a selected portion of the population (see also Gobster 1998, Byrne and Wolch 2009). Societal relations also concern knowledge gaps relating to the identification of an optimal way of communicating positive and negative examples (failures) of $\mathrm{NbS}$.

The third knowledge gap concerns the design of $\mathrm{NbS}$ and the question of how existing technical knowledge from architects and engineers can inform $\mathrm{NbS}$ to design and integrate $\mathrm{NbS}$ alongside existing grey infrastructure. An additional unknown is what the optimal design of different $\mathrm{NbS}$ can look like to best serve multiple purposes in parallel. For instance, there is increasing evidence on the potential of green roofs and façades for enhancing climate regulation and counteracting urban heat island effects (e.g., "Green Living Room Ludwigsburg" TURAS-project, http://www.turascities.org/case study). Workshop participants clearly stated that although knowledge is already available on the implementation of such solutions at the city level (e.g., greening roofs and façades in Levallius 2005, Yang et al. 2008, Scherba et al. 2011, Hunter et al. 2014, Santamouris 2014), gaps remain that relate to questions such as the following: What technical knowledge and skills are required for multifunctional urban planning and how can this knowledge be included and interlinked with knowledge on environmental and social systems to produce the best possible synergies for, e.g., climate adaptation and mitigation?

Another important knowledge gap relates to the implementation of $\mathrm{NbS}$. More specifically, urban administrations may lack information on legal instruments and requirements for implementing $\mathrm{NbS}$. It is also not clear what kind of $\mathrm{NbS}$ fits best with city development goals, although this depends largely on the context of each city. Workshop participants concluded that evidence is needed on how to deal with conflicts of interest, such as competing land uses due to differing goals and ideas of landowners in growing cities. When city populations are increasing 
and new residential space needs to be developed, the question arises of how green spaces can ideally be further developed and maintained within the context of climate change adaptation and mitigation. Here, strategic planning of green infrastructure will be instrumental to avoid piecemeal approaches and instead to integrate $\mathrm{NbS}$ into a multifunctional and connected system of green and blue spaces in the city (Pauleit et al. 2011, Hansen and Pauleit 2014). Improved knowledge is required on the instruments and tools needed to successfully implement $\mathrm{NbS}$. There is a need to identify good-practice strategies for planning and implementing $\mathrm{NbS}$ and generating more knowledge on the costefficiency of $\mathrm{NbS}$ in comparison to other, more conventional (engineered) approaches (Secretariat of the Convention on Biological Diversity 2009). This comparison should include a long-term perspective and the range of possible cobenefits that can be produced.

\section{Potential barriers to $\mathrm{NbS}$}

A broad range of potential barriers to the implementation and up-scaling of $\mathrm{NbS}$ as tools for climate change mitigation and adaption were raised at the expert workshop. These aspects have been clustered into the following categories (Fig. 3): fear of the unknowns, the disconnect between short-term actions and longterm goals, the discontinuity between short-term actions and long-term plans, sectoral silos, and the paradigm of growth. Understanding these barriers and the interconnected factors that reinforce them is essential not only for gathering evidence and knowledge to overcome those that are a matter of perception, but also for finding opportunities to address them.

Fig. 3. Combination of barrier circle and opportunities that facilitate action for nature-based solutions in urban areas.

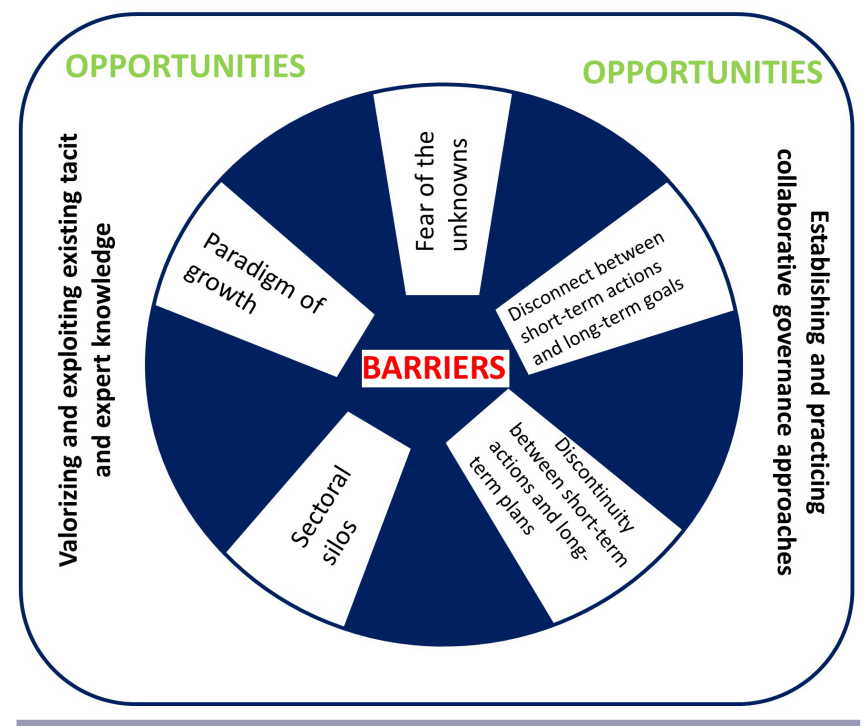

The "fear of the unknowns" considers both uncertainties and risks of implementing $\mathrm{NbS}$ in cities, as well as the resulting changes this may induce in city planning. Because of their nature, $\mathrm{NbS}$ must be handled differently than other approaches and require new protocols for implementation and maintenance; these factors are perceived as an operational unknown. Additionally, $\mathrm{NbS}$ have not yet received assessments of their effectiveness in dealing with climate mitigation and adaptation targets such as carbon offsets that may also create a performance unknown. This may be related to the lack of awareness regarding climate changeinduced problems and the benefits $\mathrm{NbS}$ can bring. Even though a number of urban planners are aware of the benefits urban green areas provide, as shown by the increasing number of green infrastructure strategies being developed, some policy makers and/or residents may not be as aware or might even have the perception that green installations on roofs and walls are harmful, e.g., are "dirty and host insects," creating additional perception hurdles (Lohr et al. 2004, Kirkpatrick et al. 2013, Kronenberg 2015). With local urban policy officers and planners often being risk averse, these unknowns create roadblocks for the uptake of $\mathrm{NbS}$ in cities.

Another barrier concerns the disconnect between short-term actions and long-term goals. Changes in administration, for example, often require long-term planning, implementation, and maintenance processes, including the sustainable designation of sufficient funds to be applied throughout the lifetime of the $\mathrm{NbS}$. This is contrary to the commonly short-term action and decisionmaking cycles within city administrations. In some cases, responsibilities for the maintenance of the project remains unspecified, which poses a risk to the continuity of delivering the desired socioeconomic and environmental benefits in the long term. Even in cities where long-term policy plans undergo adaptive monitoring for taking up new innovative solutions, scientifically validated options and knowledge are often not available at the time that the policy windows are receptive to new ideas. In a comprehensive comparison of green infrastructure planning and implementation in a number of European cities, Davies et al. (2015) identified that frameworks for green infrastructure policies generally concern long-term visions that may have to be modified when policy objectives change during new political cycles. Overall, these factors result in a disconnect between policy receptiveness and ready-to-apply scientific results and concepts (Frantzeskaki and Tilie 2014, Spruijt et al. 2014, Hansen et al. 2015).

In parallel, there is also discontinuity between short-term actions and how they relate or build up to long-term plans and goals. A number of projects researching $\mathrm{NbS}$ more generally and looking specifically at implementation aspects only exist for a certain (short) time; there is, however, the need for long-term projects, particularly regarding solutions about how to address implementation and maintenance after the project and related funding end. This is mirrored in the activities working to develop long-term ecological research (with research sites established all over the world; see http://www.ilternet.edu) into long-term socialecological research (Ohl et al. 2010). The focus is suggested to not only rest on researching the design and early-stage implementation of $\mathrm{NbS}$, but also to enable a monitoring of the impacts they have in terms of human-environment relationships over time.

Another major barrier to action that was highlighted during workshop discussion rounds refers to the traditional structures of city departments and them commonly having their own "sectoral language." Knowledge is thus trapped in "sectoral silos" (Naumann et al. 2011, Frantzeskaki and Tillie 2014, Hansen et al. 2015). Furthermore, city departments have defined fields of 
duty and restricted responsibilities, where multifaceted fields of responsibilities or projects such as $\mathrm{NbS}$ often may not fit into existing decision-making structures. Relating to this, an associated barrier to action also refers to "strong stakeholders" with whom a city or municipality has to set up interactions; they include other public bodies such as housing associations, investors, or developers (Davies et al. 2015).

The last barrier concerns the paradigm of growth and the symbol of growth to which cities adhere. Even within the context of economic and demographic decline, cities promote growth strategies and growth-dominated visions that we label as "the growth obsession barrier." For example, Kabisch and Haase (2013) identified that in shrinking European cities, the percentage of urban green-space cover sharply decreased, whereas urban residential areas significantly increased regardless of population growth or decline. Increases in built-up area including spaces for commerce, infrastructure, etc. seems to be the main focus for development, even under conditions of population decline (Haase et al. 2013). The focus remains on economic growth-oriented issues (creating jobs, attract investments), while less attention and money remains for the development of urban green spaces and the related benefits of $\mathrm{NbS}$. City budgets for green development and the maintenance of green spaces often face severe budget constraints, while staff and related expertise is decreasing (Baur et al. 2013, Davies et al. 2015, Kabisch 2015). Tight financial and time budgets combined with reductions in staff and expertise may also lead to not using existing funding options for green space implementation projects. EU-funding instruments are available for cities, but they are complicated to apply for (requiring additional administrative staff and time) and, more importantly, require cofinancing, which many cities cannot afford.

\section{Opportunities facilitating action for $\mathrm{NbS}$}

Opportunities that facilitate action for $\mathrm{NbS}$ may arise from areas such as knowledge valorization and sharing, public opinion and perception, path dependencies in policy, funding, use, and resource constraints, or the influence of other sectors. The concept of $\mathrm{NbS}$ is expected to shift the discourse in policy and science from focusing on barriers to offering solutions that create opportunities for achieving urban sustainability. As a new concept, however, $\mathrm{NbS}$ are not free from the existing pathologies in the urban governance context that are formed by both barriers and opportunities. During the workshop with experts and practitioners, several areas of opportunity were recognized that, if instrumentalized, can serve to catalyze the uptake of $\mathrm{NbS}$ by cities (these are listed around the barrier cycle in Fig. 3).

The first opportunity area is about valorizing and exploiting the existing tacit and expert knowledge of policy makers, policy advisors, urban citizens, researchers, and urban planners about $\mathrm{NbS}$ in cities (Moseley et al. 2013, Krasny et al. 2014). Knowledge gained through experiences with implementing successful projects where urban green spaces were introduced, improved in quality, or restored as well as lessons learned from less successful projects is deemed as being instrumental for effectively employing $\mathrm{NbS}$ in urban planning. This knowledge is, however, only able to be put in practice when new actors or stakeholders engage with those networks that are created or have acquired the experiences. Demonstration projects on $\mathrm{NbS}$ and adaptation in cities have created collaborative networks and communities of practice across institutional boundaries that are the levers for legitimizing new planning practices and concepts (Moore and Westley 2011, Boyd et al. 2015). Engaging and further extending those communities via the introduction and invigoration of the promises of the $\mathrm{NbS}$ concept can be essential for the quick uptake and integration into existing knowledge and for overcoming tensions between different stakeholders and fostering engagement with multiple knowledge-holders.

Multiple proposals were generated for facilitating knowledge valorization at the workshop. For example, it was suggested to establish a knowledge platform or platforms with a particular focus on cities. These are envisioned to be accessible and open for knowledge gathering, aggregating, and cocreating as a $\mathrm{NbS}$ stewardship community (Bodin and Crona 2009, Crona and Hubacek 2010, Fisher et al. 2012) that adheres to the principles of knowledge sharing (Connolly et al. 2013, Debarbieux et al. 2014) and generative learning (Richter et al. 2015). In conjunction with the NbS stewardship community, the second proposal for knowledge valorization includes the empowerment of $\mathrm{NbS}$ ambassadors to promote $\mathrm{NbS}$ and engage in a science-community advocacy for $\mathrm{NbS}$ by making $\mathrm{NbS}$ benefits and risks communicable to citizens and politicians alike. $\mathrm{NbS}$ ambassadors can serve as environmental icons and be promoted as "rock-stars" with the skills and talent to create new narratives about $\mathrm{NbS}$ and act as "belief-managers" who volunteer to not only spread the message, but who also lead the debate by being "widespread and persistent even though it involves personal costs" (Arbak and Villeval 2013:638, Johnson et al. 2014).

The second opportunity area is about the establishment and utilization of collaborative governance approaches in which policy officers collaborate with citizens, businesses, and civil society, including, but not limited to NGOs, to connect demands for action with responsible actors or partnerships for action and jointly ensure good governance practices adhering to transparency, legitimacy, and openness. The partnering of different actors may reduce barriers or constraints for adopting $\mathrm{NbS}$ as well as for their implementation in cities (Graham and Ernstson 2012, Frantzeskaki et al. 2014). Specifically, collaborative arrangements enable the distributed responsibilities that further foster a shift from risk aversion to sharing the risk of new solutions like NbS (Visseren-Hamakers et al. 2012). Partnerships that make concentrated efforts to involve the urban government are crucial for opening space for innovative approaches and solutions like $\mathrm{NbS}$ to find fertile ground for experimentation and for a rapid transfer from concepts to action. Within these partnerships and collaborative arrangements, municipalities can adopt an action-thinking approach, e.g., declaring action with and for $\mathrm{NbS}$ as a duty task for municipalities (Hamann and April 2013, Woolthuis et al. 2013, Frantzeskaki et al. 2016).

In line with the above factors, the first proposal for collaborative governance for $\mathrm{NbS}$ includes the provisioning of incentives and/ or the removal of administrative barriers to allow for partnerships to emerge between city governments and businesses as well as with citizen organizations. The resource and governance synergies that are put to work with such partnerships can create new opportunities for an efficient uptake of $\mathrm{NbS}$ (see VisserenHamakers et al. 2012, Frantzeskaki et al. 2014). A second 
proposal for fostering collaborations and new partnerships is for local and translocal governments to create conditions for new business and finance models by divesting from dominant solutions, e.g., investments in optimizing efficiency of grey infrastructure as the one and only focus, and by leveraging private and public funding in strengthening $\mathrm{NbS}$ (European Commission 2015). A third proposal concerns how to learn from emerging partnerships between civil societies the modes of selfgovernance in cities (Coaffee and Deas 2008). Grassroots innovations and transition initiatives as collaborative networks of citizens play a significant role in advocating and practicing $\mathrm{NbS}$ in cities as re-establishing green urban commons (Anguelovski 2013, Bendt et al. 2013, Colding and Barthel 2013), providing on-the-ground evidence of the multiple benefits of $\mathrm{NbS}$.

\section{CONCLUSIONS}

A number of issues should be added to science and policy agendas when dealing with climate change adaptation and mitigation measures through the instrument of $\mathrm{NbS}$. We thus conclude by highlighting three main needs for future science and policy agendas when dealing with $\mathrm{NbS}$. These needs have been identified by all workshop participants in the final plenary discussion, building on the existing evidence presented in this paper. It should be noted, however, that although the discussion exclusively centers around European research, policy, and society experience and examples, the findings nevertheless have clear applications and knowledge transfer potential to other parts of the world.

\section{Produce stronger evidence of $\mathrm{NbS}$ for climate change adaptation and mitigation and raise awareness by increasing implementation}

Further research is necessary to assess the effectiveness of $\mathrm{NbS}$ and compare it with technology-based solutions when being implemented for the purpose of addressing climate change adaptation and mitigation. Although a number of applied examples already exist (Secretariat of the Convention on Biological Diversity 2009, Naumann et al. 2011, 2014), significant additional research as well as on-site monitoring should be conducted to develop a sound evidence base and highlight efficient implementation, functioning, and costeffectiveness aspects of $\mathrm{NbS}$ in cities. Considering the latter aspect, multiple social, economic, and environmental cobenefits have to be included in these calculations as well as the potential time lags occurring before the benefits and advantages of using $\mathrm{NbS}$ become evident. Although learning from failures would be desirable, obtaining information on these aspects is very difficult. Concerning specific green infrastructure elements and designs, e.g., green rooftops or walls as well as bioswales as road limits, more research is needed that clearly illustrates effectiveness through indicators. Despite the increasing implementation of, for example, green and "constructed wetland-like" approaches to the management of local stormwater that complement conventional sewage systems with $\mathrm{NbS}$, a comprehensive understanding of the complementary benefits of technical solutions and $\mathrm{NbS}$ is still missing. A similar recommendation comes from the H2020 expert group on "Nature-Based Solutions and Re-Naturing Cities" that calls for "[...] more comprehensive evidence base on the social, economic and environmental effectiveness of possible nature-based solutions [...]" (European Commission 2015:21). We go one step further and ask for good practice examples on the real integration and exchange of expert knowledge from engineers, architects, and landscape designers to include their (technical) knowledge in discussion rounds on urban green space planning for $\mathrm{NbS}$. Potential options for how to overcome the barriers in the cooperation between these disciplines for the integration of $\mathrm{NbS}$ with technical solutions have been discussed, e.g., by Fryd et al. (2010) and Backhaus and Fryd (2012).

Moreover, sound evidence related to the impacts of climate change on biodiversity and its linkages to $\mathrm{NbS}$ and ecosystem services in cities has to be taken into account. For instance, higher urban temperatures based on the urban heat island effect were shown to be a main stressor to which urban biodiversity, particularly trees, is exposed (Schmitt et al. 2014); however, the impact of climate change-related temperature increases on biodiversity remains unclear. More evidence is needed concerning the role of urban species community composition and configuration for efficient climate change adaptation and mitigation, e.g., in decreasing air temperature or increasing air moisture to list two important effects. This relates to concerns about the number and diversity of species in cities and their effect on city resilience toward climate change and which aspects of biodiversity are relevant for ecosystem service provision, e.g., habitat diversity, species richness, functional diversity, or others. $\mathrm{NbS}$ might not always only be provided by diverse systems, but also by single keystone species. In this respect, more research is needed for the identification of synergies and trade-offs among species biodiversity features, such as species composition and ecosystem functioning, and ecosystem services under climate change, as well as disservices of green and blue infrastructure.

\section{Adapt for governance challenges in implementing $\mathrm{NbS}$}

A significant challenge for city administrations is the allocation of a sufficient budget for implementing and maintaining green space projects in cities' tight financial periods (Hansen et al. 2015, Kabisch 2015). Efforts that favor sustaining activities on a longterm basis should be embedded in NbS projects. There will not be a "one size fits all" solution because this will depend on local contexts. Strategically selected NbS could be highlighted as goodpractice examples and communicated as "rock-stars of $\mathrm{NbS}$ " (or flagship projects) to city officials, local entrepreneurs, investors, and other actors including city residents and community groups. This strategy may increase awareness about the benefits offered by $\mathrm{NbS}$. Highlighting good practice examples and promoting $\mathrm{NbS}$ in general might be possible by bridging silos through communicating the multiple benefits of $\mathrm{NbS}$ across sectors and departments. Using ad hoc or problem-based governance while focusing on a better use of existing finance instruments and linking biodiversity and climate change efforts may help in implementing strategies on $\mathrm{NbS}$. Midterm financial schemes to better highlight the "rock-stars" and to give them a chance to show their potential may also be one option. Implementation projects may then be transferred to long-term approaches in terms of development, implementation, maintenance, and financing of $\mathrm{NbS}$ projects, which is key for climate change adaptation and mitigation measures. Research on cost effectiveness of implementing NbS might help to justify new investments and to promote long-term funding or public-private arrangements. Bold 
sustainability agendas may be realized through different forms of cooperation that could be also done in $\mathrm{NbS}$ programs, to allow for different forms of partnerships to take the implementation task on board (Frantzeskaki et al. 2014). Reflexive governance as a model that considers partnering or collaborative governance arrangements and local governance structures may be the one applicable for social-ecological innovations such as NbS (Pereira et al. 2015). This would also include learning from and being aware of failures and including them in reflexive governance discussions. Multiple actors possessing different types and degrees of knowledge could then engage in a reflective way to update their planning, governance, knowledge production practice over time to continuously address arising risks and uncertainties. More reflexive approaches to urban governance further implies bringing together the new networks in society, NbS ambassadors, and newly introduced practitioners. This will deepen the extent of learning on how to implement $\mathrm{NbS}$ and extend the knowledge gained by reflecting on failures and contradictions in planning and implementation processes.

\section{Consider socio-environmental justice and social cohesion when implementing $\mathrm{NbS}$}

When promoting urban green and blue areas through $\mathrm{NbS}$, the cobenefits that citizens receive from urban nature are often highlighted. However, NbS may not always be beneficial for all population groups in the same way or to the same degree, and some benefits may take several years or decades to come into full effect. Improved availability of urban green spaces may not increase social coherence, as promoted in the Final Report of the 2020 Expert Group (European Commission 2015). Instead, improvements and increases in the size and quality of urban green spaces might go hand in hand with increasing land prices and rent (Dooling 2009, Seymour et al. 2010, Checker 2011). In turn, this could lead to the potential displacement of population groups who cannot afford the higher prices and for whom the green space would be most beneficial. It can thus be questioned if $\mathrm{NbS}$ lead to a reconnection of people to nature in cases where increasing rent prices force them to move into areas with a lower residential quality. New modes of governance are thus necessary to take into account an integrative and transdisciplinary participation of diverse residents, thereby counteracting displacement processes. Integrated approaches are required to make sure that housing at affordable prices is provided while simultaneously bettering the environment.

This paper strengthens the merits of $\mathrm{NbS}$ by focusing on implementation aspects and brings this solution-concept to urban governance and practice while opening the debate on social, economic, and ecological aspects to be considered. The concept of $\mathrm{NbS}$ holds significant potential for enhancing climate change mitigation and adaptation in urban areas and for contributing to the resilience and livability of cities. However, further research is needed to collect evidence on the effectiveness of $\mathrm{NbS}$. Efforts in this field should also invest in wide-scale implementation, learning-by-doing, advancing through experience, etc. In particular, successful strategies for the implementation and management of $\mathrm{NbS}$ in the urban environment and appropriate governance frameworks need to be developed and communicated to policy and society. By creating demonstration sites to assess $\mathrm{NbS}$ in practice, municipalities can develop pilot areas and adaptive management tools to refine the performance of $\mathrm{NbS}$ actions toward climate change mitigation and adaptation objectives as well as maximize cobenefits for society and biodiversity. $\mathrm{NbS}$ needs to be recognized and developed as proactive investment and supported as such in planning procedures and fostered in joint dialogues between policy, society, and science.

Responses to this article can be read online at: http://www.ecologyandsociety.org/issues/responses. $\mathrm{php} / 8373$

\section{Acknowledgments:}

We would like to sincerely thank all participants for their active contribution to the expert workshop on which this paper builds. The workshop was hosted by the German Federal Agency for Nature Conservation on 10-11 March 2015, Isle of Vilm, Germany (full workshop information at https://www.bfn.de/22641+M52087573ab0. html). The author team is responsible for the insights presented in this paper. This work was supported by the German Federal Agency for Nature Conservation with funds of the German Federal Ministry for the Environment, Nature Conservation, Building and Nuclear Safety through the research project "Conferences on Climate Change and Biodiversity" (BIOCLIM, project duration from 2014-2017, funding code: $351480020 \mathrm{~A}$ ).

\section{LITERATURE CITED}

Alexandri, E., and P. Jones. 2008. Temperature decreases in an urban canyon due to green walls and green roofs in diverse climates. Building and Environment 43(4):480-493. http://dx.doi. org/10.1016/j.buildenv.2006.10.055

Anguelovski, I. 2013. Beyond a livable and green neighborhood: asserting control, sovereignty and transgression in the Casc Antic of Barcelona. International Journal of Urban and Regional Research 37(3):1012-1034. http://dx.doi.org/10.1111/1468-2427.12054

Arbak, E., and M.-C. Villeval. 2013. Voluntary leadership: motivation and influence. Social Choice and Welfare 40 (3):635-662. http://dx.doi.org/10.1007/s00355-011-0626-2

Artmann, M., and J. Breuste. 2015. Cities built for and by residents: soil sealing management in the eyes of urban dwellers in Germany. Journal of Urban Planning and Development 141(3): A5014004. http://dx.doi.org/10.1061/(asce)up.1943-5444.0000252

Backhaus, A., and O. Fryd. 2012. Analyzing the first loop design process for large-scale sustainable urban drainage system retrofits in Copenhagen, Denmark. Environment and Planning $B$ 39:820-837. http://dx.doi.org/10.1068/b37088

Balian, E., H. Eggermont, and X. Le Roux. 2014. Outcomes of the strategic foresight workshop. BiodivERsA Strategic Foresight workshop, Nature-based solutions in a BiodivERsA context. Brussels June 11-12. [online] URL: http://www.biodiversa. org/687/download

Baur, J. W. R., J. F. Tynon, and E. Gómez. 2013. Attitudes about urban nature parks: a case study of users and nonusers in Portland, Oregon. Landscape and Urban Planning 117:100-111. http://dx.doi.org/10.1016/j.landurbplan.2013.04.015 
Bendt, P., S. Barthel, and J. Colding. 2013. Civic greening and environmental learning in public-access community gardens in Berlin. Landscape and Urban Planning 109(1):18-30. http://dx. doi.org/10.1016/j.landurbplan.2012.10.003

Beninde, J., M. Veith, and A. Hochkirch. 2015. Biodiversity in cities needs space: a meta-analysis of factors determining intraurban biodiversity variation. Ecology Letters 18(6):581-592. http://dx.doi.org/10.1111/ele.12427

Bodin, Ö., and B. I. Crona. 2009. The role of social networks in natural resource governance: What relational patterns make a difference? Global Environmental Change 19(3):366-374. http:// dx.doi.org/10.1016/j.gloenvcha.2009.05.002

Bowler, D. E., L. Buyung-Ali, T. M. Knight, and A. S. Pullin. 2010. Urban greening to cool towns and cities: a systematic review of the empirical evidence. Landscape and Urban Planning 97 (3):147-155. http://dx.doi.org/10.1016/j.landurbplan.2010.05.006

Boyd, E., B. Nykvist, S. Borgström, and I. A. Stacewicz. 2015. Anticipatory governance for social-ecological resilience. Ambio 44(S1):149-161. http://dx.doi.org/10.1007/s13280-014-0604-X

Byrne, J., and J. Wolch. 2009. Nature, race, and parks: past research and future directions for geographic research. Progress in Human Geography 33(6):743-765. http://dx.doi. org/10.1177/0309132509103156

Carrus, G., M. Scopelliti, R. Lafortezza, G. Colangelo, F. Ferrini, F. Salbitano, M. Agrimi, L. Portoghesi, P. Semenzato, and G. Sanesi. 2015. Go greener, feel better? The positive effects of biodiversity on the well-being of individuals visiting urban and peri-urban green areas. Landscape and Urban Planning 134:221-228. http://dx.doi.org/10.1016/j.landurbplan.2014.10.022

Checker, M. 2011. Wiped out by the "Greenwave": environmental gentrification and the paradoxical politics of urban sustainability. City and Society 23(2):210-229. http://dx.doi.org/10.1111/ j.1548-744x.2011.01063.x

Coaffee, J., and I. Deas. 2008. The search for policy innovation in urban governance: lessons from community-led regeneration partnerships. Public Policy and Administration 23(2):167-187. http://dx.doi.org/10.1177/0952076707086254

Colding, J., and S. Barthel. 2013. The potential of "Urban Green Commons" in the resilience building of cities. Ecological Economics 86:156-166. http://dx.doi.org/10.1016/j.ecolecon.2012.10.016

Colls, A., N. Ash, and N. Ikkala. 2009. Ecosystem-based adaptation: a natural response to climate change. International Union for Conservation of Nature, Gland, Switzerland.

Connolly, J. J., E. S. Svendsen, D. R. Fisher, and L. K. Campbell. 2013. Organizing urban ecosystem services through environmental stewardship governance in New York City. Landscape and Urban Planning 109(1):76-84. http://dx.doi.org/10.1016/j.

landurbplan.2012.07.001

Cowan, C., C. Epple, H. Korn, R. Schliep, and J. Stadler, editors. 2010. Working with nature to tackle climate change. German Federal Agency for Nature Conservation, Bonn, Germany.

Crona, B., and K. Hubacek. 2010. The right connections: How do social networks lubricate the machinery of natural resource governance? Ecology and Society 15(4):18. [online] URL: http:// www.ecologyandsociety.org/vol15/iss4/art18/

Davies, C., R. Hansen, E. Rall, S. Pauleit, R. Lafortezza, Y. De Bellis, A. Santos, and I. Tosics. 2015. Green infrastructure planning and implementation - the status of European green space planning and implementation based on an analysis of selected European cityregions. European Commission, Brussels, Belgium.

Debarbieux, B., J. Balsiger, D. Djordjevic, S. Gaberell, and G. Rudaz. 2014. Scientific collectives in region-building processes. Environmental Science \& Policy 42:149-159. http://dx.doi. org/10.1016/j.envsci.2014.06.005

de Groot, R. S., M. A. Wilson, and R. M. J. Boumans. 2002. A typology for the classification, description and valuation of ecosystem functions, goods and services. Ecological Economics 41(3):393-408. http://dx.doi.org/10.1016/s0921-8009(02)00089-7

Dooling, S. 2009. Ecological gentrification: a research agenda exploring justice in the city. International Journal of Urban and Regional Research 33(3):621-639. http://dx.doi.org/10.1111/ j.1468-2427.2009.00860.x

Doswald, N., and M. Osti. 2011. Ecosystem-based approaches to adaptation and mitigation - good practice examples and lessons learned in Europe. BfN-Skripten 306.

European Commission. 2015. Towards an EU research and innovation policy agenda for nature-based solutions and re-naturing cities. Final Report of the Horizon 2020 expert group on "NatureBased Solutions and Re-Naturing Cities." European Commission, Brussels, Belgium.

European Environmental Agency. 2012. Climate change, impacts and vulnerability in Europe 2012. An indicator-based report. European Environmental Agency, Copenhagen, Denmark.

Everard, M., and R. McInnes. 2013. Systemic solutions for multibenefit water and environmental management. Science of The Total Environment 461-462:170-179. http://dx.doi.org/10.1016/j. scitotenv.2013.05.010

Fisher, D. R., L. K. Campbell, and E. S. Svendsen. 2012. The organisational structure of urban environmental stewardship. Environmental Politics 21(1):26-48. http://dx.doi. org/10.1080/09644016.2011.643367

Frantzeskaki, N., S. Jhagroe, and M. Howlett. 2016. Greening the state? The framing of sustainability in Dutch infrastructure governance. Environmental Science \& Policy 58:123-130. http:// dx.doi.org/10.1016/j.envsci.2016.01.011

Frantzeskaki, N., and N. Tilie. 2014. The dynamics of urban ecosystem governance in Rotterdam, the Netherlands. Ambio 43 (4):542-555. http://dx.doi.org/10.1007/s13280-014-0512-0

Frantzeskaki, N., J. Wittmayer, and D. Loorbach. 2014. The role of partnerships in 'realising' urban sustainability in Rotterdam's City Ports Area, the Netherlands. Journal of Cleaner Production 65:406-417. http://dx.doi.org/10.1016/j.jclepro.2013.09.023

Fryd, O., M. B. Jensen, S. T. Ingvertsen, J. Jeppesen, and J. Magid. 2010. Doing the first loop of planning for sustainable urban drainage system retrofits: a case study from Odense, Denmark. Urban Water Journal 7(6):367-378. http://dx.doi.

org/10.1080/1573062x.2010.527352 
Gill, S. E., J. F. Handley, A. R. Ennos, and S. Pauleit. 2007. Adapting cities for climate change: the role of the green infrastructure. Built Environment 33:115-133. http://dx.doi. org/10.2148/benv.33.1.115

Gobster, P. H. 1998. Urban parks as green walls or green magnets? Interracial relations in neighborhood boundary parks. Landscape and Urban Planning 41(1):43-55. http://dx.doi.org/10.1016/ s0169-2046(98)00045-0

Goddard, M. A., A. J. Dougill, and T. G. Benton. 2010. Scaling up from gardens: biodiversity conservation in urban environments. Trends in Ecology \& Evolution 25(2):90-98. http:// dx.doi.org/10.1016/j.tree.2009.07.016

Graham, M., and H. Ernstson. 2012. Comanagement at the fringes: examining stakeholder perspectives at Macassar Dunes, Cape Town, South Africa-at the intersection of high biodiversity, urban poverty, and inequality. Ecology and Society 17(3):34. http://dx.doi.org/10.5751/es-04887-170334

Grimm, N. B., S. H. Faeth, N. E. Golubiewski, C. L. Redman, J. Wu, X. Bai, and J. M. Briggs. 2008. Global change and the ecology of cities. Science 319(5864):756-760. http://dx.doi.org/10.1126/ science. 1150195

Haase, D., N. Kabisch, and A. Haase. 2013. Endless urban growth? On the mismatch of population, household and urban land area growth and its effects on the urban debate. PLoS ONE 8(6):e66531. http://dx.doi.org/10.1371/journal.pone.0066531

Haase, D., N. Larondelle, E. Andersson, M. Artmann, S. Borgström, J. Breuste, E. Gomez-Baggethun, Å. Gren, Z. Hamstead, R. Hansen, N. Kabisch, P. Kremer, J. Langemeyer, E. L. Rall, T. McPhearson, S. Pauleit, S. Qureshi, N. Schwarz, A. Voigt, D. Wurster, and T. Elmqvist. 2014. A quantitative review of urban ecosystem service assessments: concepts, models, and implementation. Ambio 43(4):413-433. http://dx.doi.org/10.1007/ s13280-014-0504-0

Haffner, J. 2015. The dangers of eco-gentrification: what's the best way to make a city greener? The Guardian, 6 May. [online] URL: http://www.theguardian.com/cities/2015/may/06/dangers-ecogentrificationbest-way-make-city-greener

Hamann, R., and K. April. 2013. On the role and capabilities of collaborative intermediary organisations in urban sustainability transitions. Journal of Cleaner Production 50:12-21. http://dx.doi. org/10.1016/j.jclepro.2012.11.017

Hansen, R., N. Frantzeskaki, T. McPhearson, E. Rall, N. Kabisch, A. Kaczorowska, J.-H. Kain, M. Artmann, and S. Pauleit. 2015. The uptake of the ecosystem services concept in planning discourses of European and American cities. Ecosystem Services 12:228-246. http://dx.doi.org/10.1016/j.ecoser.2014.11.013

Hansen, R., and S. Pauleit. 2014. From multifunctionality to multiple ecosystem services? A conceptual framework for multifunctionality in green infrastructure planning for urban areas. Ambio 43(4):516-529. http://dx.doi.org/10.1007/s13280-014-0510-2

Hartig, T., R. Mitchell, S. de Vries, and H. Frumkin. 2014. Nature and health. Annual Review of Public Health 35:207-228. http://dx. doi.org/10.1146/annurev-publhealth-032013-182443

Hunter, A. M., N. S. G. Williams, J. P. Rayner, L. Aye, D. Hes, and S. J. Livesley. 2014. Quantifying the thermal performance of green façades: a critical review. Ecological Engineering 63:102-113. http://dx.doi.org/10.1016/j.ecoleng.2013.12.021

Irvine, K. N., S. L. Warber, P. Devine-Wright, and K. J. Gaston. 2013. Understanding urban green space as a health resource: a qualitative comparison of visit motivation and derived effects among park users in Sheffield, UK. International Journal of Environmental Research and Public Health 10(1):417-442. http:// dx.doi.org/10.3390/ijerph10010417

Johnson, M. F., C. Hannah, L. Acton, R. Popovici, K. K. Karanth, and E. Weinthal. 2014. Network environmentalism: citizen scientists as agents for environmental advocacy. Global Environmental Change 29:235-245. http://dx.doi.org/10.1016/j. gloenvcha.2014.10.006

Kabisch, N. 2015. Ecosystem service implementation and governance challenges in urban green space planning: the case of Berlin, Germany. Land Use Policy 42:557-567. http://dx.doi. org/10.1016/j.landusepol.2014.09.005

Kabisch, N., A. Bonn, J. Stadler, and H. Korn. 2015b. Naturebased solutions to climate change mitigation and adaptation in urban areas and their rural surroundings - successes, challenges and evidence gaps - towards management and policy recommendations. BfN-Expert workshop documentation, Vilm, 10-11 March. German Federal Agency for Nature Conservation, Bonn, Germany.

Kabisch, N., and D. Haase. 2013. Green spaces of European cities revisited for 1990-2006. Landscape and Urban Planning 110:113-122. http://dx.doi.org/10.1016/j.landurbplan.2012.10.017

Kabisch, N., S. Qureshi, and D. Haase. 2015a. Humanenvironment interactions in urban green spaces - a systematic review of contemporary issues and prospects for future research. Environmental Impact Assessment Review 50:25-34. http://dx.doi. org/10.1016/j.eiar.2014.08.007

Keniger, L. E., K. J. Gaston, K. N. Irvine, and R. A. Fuller. 2013. What are the benefits of interacting with nature? International Journal of Environmental Research and Public Health 10 (3):913-935. http://dx.doi.org/10.3390/ijerph10030913

Kirkpatrick, J. B., A. Davison, and A. Harwood. 2013. How tree professionals perceive trees and conflicts about trees in Australia's urban forest. Landscape and Urban Planning 119:124-130. http:// dx.doi.org/10.1016/j.landurbplan.2013.07.009

Knapp, S., I. Kuehn, J. Stolle, and S. Klotz. 2010. Changes in the functional composition of a Central European urban flora over three centuries. Perspectives in Plant Ecology Evolution and Systematics 12:235-244. http://dx.doi.org/10.1016/j.ppees.2009.11.001

Krasny, M. E., A. Russ, K. G. Tidball, and T. Elmqvist. 2014. Civic ecology practices: participatory approaches to generating and measuring ecosystem services in cities. Ecosystem Services 7:177-186. http://dx.doi.org/10.1016/j.ecoser.2013.11.002

Kronenberg, J. 2015. Why not to green a city? Institutional barriers to preserving urban ecosystem services. Ecosystem Services 12:218-227. http://dx.doi.org/10.1016/j.ecoser.2014.07.002

Levallius, J. 2005. Green roofs on municipal buildings in Lundmodeling potential environmental benefits. Thesis. Department of Physical Geography and Ecosystem Analysis, Lund University, Sweden. 
Lohr, V. I., C. H. Pearson-Mims, J. Tarnai, and D. A. Dillman. 2004. How urban residents rate and rank the benefits and problems associated with trees in cities. Journal of Arboriculture 30:28-35.

Lyytimäki, J., and M. Sipilä. 2009. Hopping on one leg - the challenge of ecosystem disservices for urban green management. Urban Forestry \& Urban Greening 8(4):309-315. http://dx.doi. org/10.1016/j.ufug. 2009.09.003

McMichael, A. J., S. Friel, A. Nyong, and C. Corvalan. 2008. Global environmental change and health: impacts, inequalities, and the health sector. BMJ 336(7637):191-194. http://dx.doi. org/10.1136/bmj.39392.473727.ad

Millennium Ecosystem Assessment. 2005. Ecosystems and human well-being: synthesis. Island Press, Washington, D.C., USA.

Moore, M., and F. Westley. 2011. Surmountable chasms: networks and social innovation for resilient systems. Ecology and Society 16(1):5. [online] URL: http://www.ecologyandsociety. org/vol16/iss 1/art5/

Moseley, D., M. Marzano, J. Chetcuti, and K. Watts. 2013. Green networks for people: application of a functional approach to support the planning and management of greenspace. Landscape and Urban Planning 116:1-12. http://dx.doi.org/10.1016/j. landurbplan.2013.04.004

Naumann, S., G. Anzaldua, P. Berry, S. Burch, M. Davis, A. Frelih-Larsen, H. Sanders, and M. Gerdes. 2011. Assessment of the potential of ecosystem-based approaches to climate change adaptation and mitigation in Europe. Final report to the European Commission. Ecologic Institute, Berlin, Germany and Environmental Change Institute, Oxford University Centre for the Environment, Oxford, UK.

Naumann, S., M. Davis, B. Goeller, L. Gradmann, A. Mederake, J. Stadler, and K. Bockmühl. 2015. Ökosystembasierte Ansätze zur Anpassung an den Klimawandel und zum Klimaschutz im deutschsprachigen Raum. BfN-Skripten. German Federal Agency for Nature Conservation ( $\mathrm{BfN}$ ), Bonn, Germany.

Naumann, S., T. Kaphengst, K. McFarland, and J. Stadler. 2014. Nature-based approaches for climate change mitigation and adaptation. German Federal Agency for Nature Conservation (BfN), Ecologic Institute, Bonn, Germany.

Niemela, J. 1999. Ecology and urban planning. Biodiversity \& Conservation 8:119-131. http://dx.doi.org/10.1023/A:1008817325994

Ohl, C., K. Johst, J. Meyerhoff, M. Beckenkamp, V. Grüsgen, and M. Drechsler. 2010. Long-term socio-ecological research (LTSER) for biodiversity protection - a complex systems approach for the study of dynamic human-nature interactions. Ecological Complexity 7:170-178. http://dx.doi.org/10.1016/j. ecocom.2009.10.002

Pauleit, S., L. Liu, J. Ahern, and A. Kazmierczak. 2011. Multifunctional green infrastructure planning to promote ecological services in the city. Pages 272-285 in J. Niemelä, editor. Urban ecology: patterns, processes, and applications. Oxford University Press, Oxford, UK. http://dx.doi.org/10.1093/acprof: oso/9780199563562.003.0033
Pereira, L., T. Karpouzoglou, S. Doshi, and N. Frantzeskaki. 2015. Organising a safe space for navigating social-ecological transformations to sustainability. International Journal of Environmental Research and Public Health 12(6):6027-6044. http://dx.doi.org/10.3390/ijerph120606027

Richardson, E. A., J. Pearce, R. Mitchell, and S. Kingham. 2013. Role of physical activity in the relationship between urban green space and health. Public Health 127(4):318-324. http://dx.doi. org/10.1016/j.puhe.2013.01.004

Richter, C. H., J. Xu, and B. A. Wilcox. 2015. Opportunities and challenges of the ecosystem approach. Futures 67:40-51. http:// dx.doi.org/10.1016/j.futures.2014.12.002

Santamouris, M. 2014. Cooling the cities - a review of reflective and green roof mitigation technologies to fight heat island and improve comfort in urban environments. Solar Energy 103:682-703. http://dx.doi.org/10.1016/j.solener.2012.07.003

Scherba, A., D. J. Sailor, T. N. Rosenstiel, and C. C. Wamser. 2011. Modeling impacts of roof reflectivity, integrated photovoltaic panels and green roof systems on sensible heat flux into the urban environment. Building and Environment 46(12):2542-2551. http:// dx.doi.org/10.1016/j.buildenv.2011.06.012

Schmitt, U., G. Koch, B. Lüer, D. Dujesiefken, and G. Koch. 2014. The Massaria disease of plane trees: its wood decay mechanism. IAWA 35(4):395-406. http://dx.doi.org/10.1163/22941932-00000074

Schröter, D., W. Cramer, R. Leemans, I. C. Prentice, M. B. Araújo, N. W. Arnell, A. Bondeau, H. Bugmann, T. R. Carter, C. A. Gracia, et al. 2005. Ecosystem service supply and vulnerability to global change in Europe. Science 310:1333-1337. http://dx.doi. org/10.1126/science. 1115233

Science for Environment Policy. 2015. Ecosystem services and the environment. In-depth Report 11 produced for the European Commission, DG Environment by the Science Communication Unit, University of the West of England, Bristol, UK.

Secretariat of the Convention on Biological Diversity. 2009. Connecting biodiversity and climate change mitigation and adaptation: report of the Second Ad Hoc Technical Expert Group on Biodiversity and Climate Change. Montréal, Québec, Canada.

Secretariat of the Convention on Biological Diversity. 2012. Cities and biodiversity outlook. Montréal, Québec, Canada.

Seto, K. C., M. Fragkias, B. Güneralp, and M. K. Reilly. 2011. A meta-analysis of global urban land expansion. PLoS ONE 6(8): e23777. http://dx.doi.org/10.1371/journal.pone.0023777

Seymour, M., J. Wolch, K. D. Reynolds, and H. Bradbury. 2010. Resident perceptions of urban alleys and alley greening. Applied Geography 30(3):380-393. http://dx.doi.org/10.1016/j.apgeog.2009.11.002

Shandas, V., and W. B. Messer. 2008. Fostering green communities through civic engagement: community-based environmental stewardship in the Portland area. Journal of the American Planning Association 74(4):408-418. http://dx.doi. org/10.1080/01944360802291265

Sparks, T. H., S. H. M. Butchard, A. Balmford, L. Bennun, D. Stanwell-Smith, M. Walpole, N. R. Bates, B. Bomhard, G. M. 
Buchanan, A. M. Chenery, B. Collen, J. Csirke, R. J. Diaz, N. K. Dulvy, C. Fitzgerald, V. Kapos, P. Mayaux, M. Tierney, M. Waycott, L. Wood, and R. E. Green. 2011. Linked indicator sets for addressing biodiversity loss. Oryx 45(03):411-419. http://dx. doi.org/10.1017/s003060531100024x

Spruijt, P., A. B. Knol, E. Vasileiadou, J. Devilee, E. Lebret, and A. C. Petersen. 2014. Roles of scientists as policy advisers on complex issues: a literature review. Environmental Science and Policy 40:16-25. http://dx.doi.org/10.1016/j.envsci.2014.03.002

The Economics of Ecosystem and Biodiversity (TEEB). 2011. The Economics of Ecosystem and Biodiversity: TEEB manual for cities: ecosystem services in urban management. TEEB, Geneva, Switzerland

Visseren-Hamakers, I. J., P. Leroy, and P. Glasbergen. 2012. Conservation partnerships and biodiversity governance: fulfilling governance functions through interaction. Sustainable Development 20(4):264-275. http://dx.doi.org/10.1002/sd.482

Von Döhren, P., and D. Haase. 2015. Ecosystem disservices research: a review of the state of the art with a focus on cities. Ecological Indicators 52:490-497. http://dx.doi.org/10.1016/j. ecolind.2014.12.027

White, M. P., I. Alcock, B. W. Wheeler, and M. H. Depledge. 2013. Would you be happier living in a greener urban area? A fixedeffects analysis of panel data. Psychological Science 24 (6):920-928. http://dx.doi.org/10.1177/0956797612464659

White, P., M. Pelling, K. Sen, D. Seddon, S. Russel, and R. Few. 2005. Disaster risk reduction: a development concern. A scoping study on links between disaster risk reduction, poverty and development. Department for International Development, London, UK.

Wolch, J. R., J. Byrne, and J. P. Newell. 2014. Urban green space, public health, and environmental justice: the challenge of making cities 'just green enough.' Landscape and Urban Planning 125:234-244. http://dx.doi.org/10.1016/j.landurbplan.2014.01.017

Woolthuis, R. K., F. Hooimeijer, B. Bossink, G. Mulder, and J. Brouwer. 2013. Institutional entrepreneurship in sustainable urban development: Dutch successes as inspiration for transformation. Journal of Cleaner Production 50:91-100. http:// dx.doi.org/10.1016/j.jclepro.2012.11.031

World Health Organization and Secretariat of the Convention on Biological Diversity. 2015. Connecting global priorities: biodiversity and human health: a state of knowledge review. Secretariat of the Convention on Biological Diversity, Montréal, Québec, Canada.

Yang, J., Q. Yu, and P. Gong. 2008. Quantifying air pollution removal by green roofs in Chicago. Atmospheric Environment 42 (31):7266-7273. http://dx.doi.org/10.1016/j.atmosenv.2008.07.003

Ziter, C. 2015. The biodiversity-ecosystem service relationship in urban areas: a quantitative review. Oikos. http://dx.doi. org/10.1111/oik.02883 
Appendix 1. List of workshop participants.

\begin{tabular}{|c|c|c|c|}
\hline No. & Type of institution & Institution & Country \\
\hline 1 & $\begin{array}{l}\text { Engineering and } \\
\text { consulting company }\end{array}$ & Krieg \& Fischer GmbH & Germany \\
\hline 2 & $\begin{array}{l}\text { European (EU) } \\
\text { administration }\end{array}$ & European Commission & Belgium \\
\hline 3 & European (EU) agency & European Environment Agency & Denmark \\
\hline 4 & Federal administration & $\begin{array}{l}\text { Nature Conservation Agency of the Czech } \\
\text { Republic }\end{array}$ & Czech Republic \\
\hline 5 & Federal administration & Swedish Environmental Protection Agency & Sweden \\
\hline 6 & $\begin{array}{l}\text { Federal administration/ } \\
\text { Research }\end{array}$ & Federal Agency for Nature Conservation & Germany \\
\hline 7 & $\begin{array}{l}\text { Federal } \\
\text { administration/Research }\end{array}$ & Federal Agency for Nature Conservation & Germany \\
\hline 8 & $\begin{array}{l}\text { Federal } \\
\text { administration/Research }\end{array}$ & Federal Agency for Nature Conservation & Germany \\
\hline 9 & Federal organisation & $\begin{array}{l}\text { GIZ - Deutsche Gesellschaft für } \\
\text { Internationale Zusammenarbeit (GIZ) GmbH }\end{array}$ & Germany \\
\hline 10 & $\begin{array}{l}\text { Non-governmental } \\
\text { organization }\end{array}$ & ECNC Green Welcome Centre Kleve & The Netherlands \\
\hline 11 & Non-profit organization & GRÜNE LIGA Berlin e.V. & Germany \\
\hline 12 & Public administration & Wernigerode (city) & Germany \\
\hline 13 & Public body & Scottish Natural Heritage & United Kingdom \\
\hline 14 & Research institute & University of Salzburg & Austria \\
\hline 15 & Research institute & $\begin{array}{l}\text { Helmholtz Centre for Environmental } \\
\text { Research - UFZ }\end{array}$ & Germany \\
\hline 16 & Research institute & $\begin{array}{l}\text { Institute of Landscape Planning and Ecology - } \\
\text { University of Stuttgart }\end{array}$ & Germany \\
\hline 17 & Research institute & DRIFT, Erasmus University Rotterdam & The Netherlands \\
\hline 18 & Research institute & $\begin{array}{l}\text { Georg-August-University Göttingen, Centre } \\
\text { of Biodiversity and Sustainable Land use } \\
\text { (CBL) }\end{array}$ & Germany \\
\hline 19 & Research institute & $\begin{array}{l}\text { Humboldt-Universität zu Berlin and } \\
\text { Helmholtz Centre for Environmental } \\
\text { Research - UFZ }\end{array}$ & Germany \\
\hline 20 & Research institute & Humboldt-Universität zu Berlin & Germany \\
\hline 21 & Research institute & $\begin{array}{l}\text { German Centre for Integrative Biodiversity } \\
\text { Research (iDiv) Halle-Jena-Leipzig and } \\
\text { Helmholtz Centre for Environmental } \\
\text { Research - UFZ }\end{array}$ & Germany \\
\hline 22 & Research institute & $\begin{array}{l}\text { German Centre for Integrative Biodiversity } \\
\text { Research (iDiv) Halle-Jena-Leipzig and } \\
\text { Helmholtz Centre for Environmental } \\
\text { Research - UFZ }\end{array}$ & Germany \\
\hline 23 & Research institute & University of Rottenburg & Germany \\
\hline 24 & Research institute & Humboldt-Universität zu Berlin & Germany \\
\hline
\end{tabular}




\begin{tabular}{|c|c|c|c|}
\hline 25 & Research institute & Ecologic Institute & Germany \\
\hline 26 & Research institute & TU München & Germany \\
\hline 27 & Research institute & $\begin{array}{l}\text { Agroecology, Georg-August-University } \\
\text { Göttingen }\end{array}$ & Germany \\
\hline 28 & Research institute & Technische Universität (TU) Berlin & Germany \\
\hline 29 & Research institute & Humboldt University of Berlin & Germany \\
\hline 30 & Research institute & Agroecology, Georg-August-University & Germany \\
\hline 31 & Research institute & UFZ Leipzig & Germany \\
\hline 32 & Research institute & $\begin{array}{l}\text { Dresden University of Applied Sciences, } \\
\text { Faculty of Agriculture/Landscape } \\
\text { Management }\end{array}$ & Germany \\
\hline 32 & Research institute & Hochschule Neubrandenburg & Germany \\
\hline
\end{tabular}

